\title{
A study of the status of exposure to polycyclic aromatic hydrocarbons (PAHs) in relation to its metabolites among workers in a Korean chemical factory
}

\author{
Um estudo sobre o estado de exposição a hidrocarbonetos \\ aromáticos policíclicos (HAPs), em relação aos seus metabolitos, \\ entre os trabalhadores em fábricas de produtos químicos coreana
}

Kwan Lee ${ }^{1}$

Hyun-Sul Lim ${ }^{1}$

Heon $\mathrm{Kim}^{2}$
${ }^{1}$ Department of Preventive Medicine, College of Medicine, Dongguk University. 123, Dongdae-ro, Gyeongju-si, Gyeongsangbuk-do, SEOUL 780-714, Republic of Korea. kwaniya@dongguk.ac.kr ${ }^{2}$ Department of Preventive Medicine, College of Medicine, Chungbuk National University.

\begin{abstract}
The study was conducted to evaluate the status of worker exposure to polycyclic aromatic hydrocarbons (PAHs) through the measurement of urinary metabolites such as 1-hydroxypyrene (OHP) and 2-naphthol. A survey using a questionnaire involving 326 workers with measurement of urinary metabolites of 1-OHP and 2-naphthol was conducted. The differences in urinary 1-OHP and 2-naphthol concentrations, and changes in work, smoking habits and lifestyle were analyzed. The number of male subjects was 314 (96.3\%), the largest age group was the fifth decade (170 cases, $52.1 \%)$. The urinary 1-OHP and 2-naphthol concentrations were significantly higher in the production workers. The urinary 1-OHP and 2-naphthol concentrations were significantly higher in smokers. In a multiple regression model, log (1-OHP) increased in smokers and production workers, while log (2-naphthol) only increased in smokers. Our results suggest that workers in this factory were exposed to PAHs from non-occupational as well as occupational sources. The occupational exposure to PAHs can be reduced through the improvement of the process, but the exposure due to smoking can be prevented only by giving up smoking.
\end{abstract}

Key words Coal tar, Polycylic aromatic hydrocarbons, 1-hydroxypyrene, 2-naphthol, Smoking
Resumo O presente estudo foi realizado para avaliar o estado de exposição a hidrocarbonetos aromáticos policíclicos (HAPs) em trabalhadores, por medição de metabólitos urinários, tais como 1-hidroxipireno (OHP) e 2-naftol. Foi realizada uma pesquisa por questionário envolvendo 326 trabalhadores e a mensuração dos metabólitos urinários de 1-OHP e 2-naftol. Foram analisadas as diferenças na urinária 1-OHP e as concentrações de 2-naftol e mudanças pelo trabalho, hábito de fumar e estilo de vida. O número de indivíduos do sexo masculino foi de 314 (96,3\%), a maior faixa etária foi a quinta década (170 casos, 52,1\%). Com relação aos metabólitos urinários 1 -OHP e 2-naftol, as concentrações foram significativamente maiores nos trabalhadores produtivos. As concentrações dos metabólitos urinários 1-OHP e 2-naftol foram significativamente maiores nos fumantes. Em um modelo de regressão múltipla, $\log (1-\mathrm{OHP})$ aumentou em fumantes e em trabalhadores produtivos, enquanto que log (2-naftol) aumentou apenas em fumantes. Nossos resultados sugerem que os trabalhadores desta fábrica foram expostos tanto a HAPs de fontes não ocupacionais como ocupacionais. A exposição ocupacional a HAPs pode ser diminuída através da melhoria do processo, mas a exposição devido ao fumo só pode ser impedida interrompendo esse hábito.

Palavras-chave Alcatrão de carvão, Hidrocarbonetos aromáticos policíclicos, 1 - hidroxipireno, 2-naftol, Tabagismo 


\section{Introduction}

Polycyclic aromatic hydrocarbons (PAHs) result from the pyrolysis or incomplete combustion of carbonaceous organic compounds. Products including anthracene, benzopyrene (benzo(a) pyrene), bitumen, carbon black, Keure creosote, coal tar pitch, naphthalene, etc., contain $\mathrm{PAHs}^{1}$. PAHs are known mainly as tumor initiators of skin and lung cancer but also are reported as carcinogens that cause bladder cancer, cancer of the larynx, kidney cancer, breast cancer, etc. ${ }^{2}$. The International Agency for Research on Cancer (IARC) prescribes aluminium, coal gas, coke manufacturing process, in which exposure to PAHs is possible through coal-tar pitch, etc., as a Group I substance, where there is a characteristic that causes cancer in the human body-8.

In addition, the environmental protection agency (EPA) has set up an index of air pollution that refers to sixteen PAHs including naphthalene, acenaphthylene, acenaphthene, fluorene, phenanthrene, anthracene, fluoranthene, pyrene, benzo(a)anthracene, chrysene, benzo(b)fluoranthene, benzo(k)fluoranthene, dibenzo(a,h)anthracene, benzo(ghi)perylene, indeno(1,2,3-cd) pyrene, benzo(a)pyrene, etc. ${ }^{9}$. IARC reports that among these PAHs, benz(a)anthracene (2A), benzo(b)fluoranthene (2B) benzo(k)fluoranthene $(2 \mathrm{~B})$, dibenzo( $\mathrm{a}, \mathrm{h})$ anthracene $(2 \mathrm{~A})$, indeno(1,2,3-cd)pyrene (2B), benzo(a)pyrene (2A), etc., have characteristics that cause cancer ${ }^{8}$. In the US, a government industrial hygiene panel (ACGIH) has determined that benzo(b)fluoranthene (A2), benzo(a)pyrene (A2), chrysene (A3), benzo(a)anthracene (A2), etc., have carcinogenic characteristics $^{10}$. The target place of this study is where workers process coal tar - whereby occupational exposure to PAHs arises - to produce tar, pitch, carbon black, etc. Coal tar is generated when solid-state organic material such as coal is carbonized; it has the consistency of a fluid and is either brown or black. There is the physical properties in which the great quantity of the PAHs is melted if it adds the heat of 200-250 since being the fluid ${ }^{11}$.

There are skin disorders including dermatitis, local telangiectasia, dermatoma, etc., and respiratory disorders including bronchitis, bronchiolitis, aveolitis, lung cancer, etc. that are associated with health problems arising from coal tar ${ }^{1}$. In Korea, so far there have been five cases of lung cancer (three involving PAHs, one case involving coke oven emissions, and one case involving coal tar pitch) related to coal $\operatorname{tar}^{12,13}$.
Much cost is entailed for measuring the PAH concentration in the work environment or the atmosphere, and there is a limit in terms of estimating the exposure through many lifestyle factors and various other modes ${ }^{14}$. Therefore, biological monitoring is an alternative for measuring the environmental exposure ${ }^{15}$. In the case of biological monitoring for PAHs, there are many biomarkers including thioethers, 1-naphthol, 2 -naphthol, $\beta$-naphthylamine, hydroxyphenanthrene, and 1-hydroxypyrene (1-OHP). And among these, 1-OHP and 2-naphthol are widely used.

This study was carried out to evaluate the workers' status of exposure to polycyclic aromatic hydrocarbons (PAHs) through the measurement of urinary metabolites such as 1-hydroxypyrene (OHP) and 2-naphthol, and an investigation of the working history and dietary and smoking habits among the workers in a chemical factory.

\section{Subjects and methods}

\section{Study population}

The subjects of this study consisted of 326 workers (314 male and 12 female) in a chemical factory. All the participants provided written and informed consent prior to participation in this study, and all the processes were reviewed and approved by the institutional review board at Dongguk University College of Medicine. This company, which is the research site, produces tar, carbon black, phthalic anhydride, plasticizer, carbomer, crude light oil, and HCP (hexachlorophene). The measurement of urinary metabolites was performed for the 326 subjects, and the changes in metabolites between before and after work were observed among 38 workers (Figure 1).

\section{Questionnaire survey}

A questionnaire survey was performed to understand the general characteristics, occupational histories, dietary habits, and smoking habits. The self-administered questionnaire was distributed before a survey 2 week in advance. After filling questionnaire, they were asked again about the omission item and checked out. The questionnaire included general questions pertaining to: sex, age, etc.; occupational history; type of occupation; working department; whether or not exposed to harmful material, etc.; dietary habits including whether or not meat (or bent meat) 


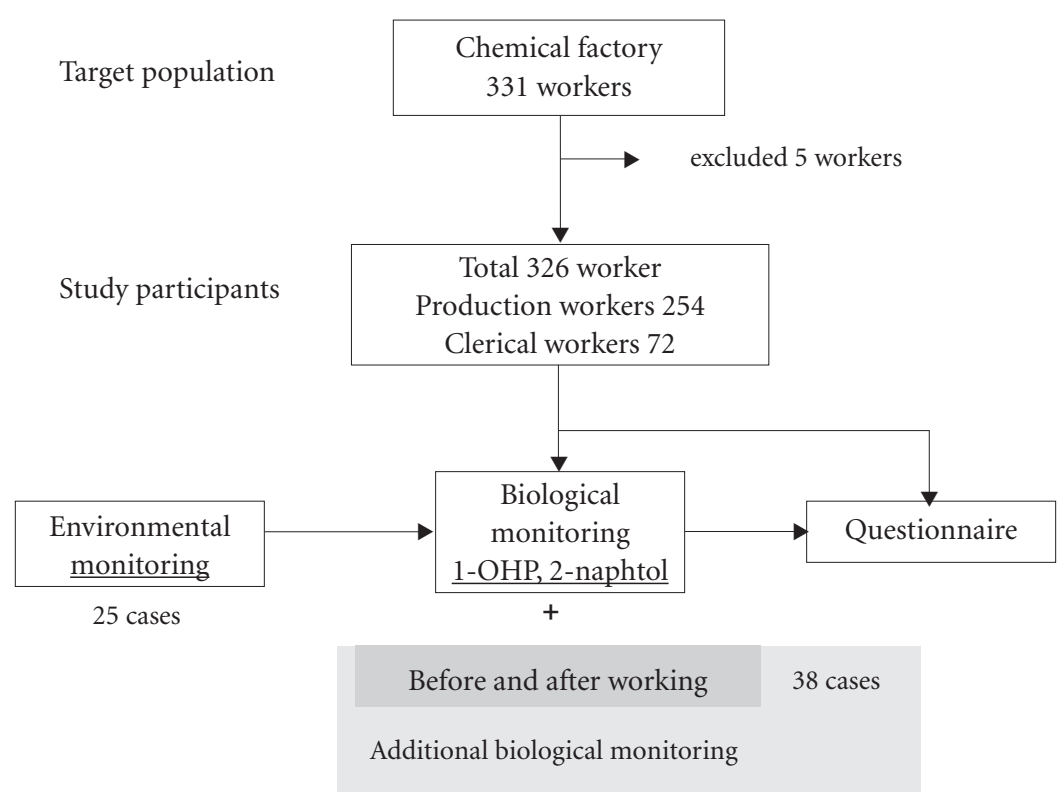

Figure 1. The flowchart of environmental and biological monitoring of personnel about chemical exposure.

was consumed and the frequency of its intake, etc.; and smoking habits including the smoked amount, amount smoked on days other than that of the examination, amount smoked on the day of the examination, and the elapsed time from final smoking.

\section{Sampling and analysis of PAHs}

Personal air sampling and analysis were conducted by NIOSH method $5515^{16}$. Personal air sampling was conducted in the 25 workers using PTFE (polytetrafluoroethylene) membrane filter $(2 \mu \mathrm{m}, 37 \mathrm{~mm}), \mathrm{XAD}-2$ tube $(100 \mathrm{mg} / 50 \mathrm{mg}$, SKC, Eighty Four, PA, USA), and personal sampling pump (Personal air sampler, Gillian, Wayne, NJ, USA) at $2 \mathrm{~L} / \mathrm{min}$. And sixteen U.S. EPA PAH including naphthalene, acenaphthylene, acenaphthene, fluorene, phenanthrene, anthracene, fluoranthene, pyrene, benzo[a]anthrancene, chrysene, benzo[b]fluoranthene, benzo[k]fluoranthene, benzo[p]pyrene, dibenz[a,h]anthracene, benzo[g,h,i]perylene, indenol[1,2,3-cd] pyrene were analyzed.

\section{Analysis of urinary 1-OHP and 2-naphthol}

For analyzing the urinary 1-OHP concentration, the authors used the method developed by Jongeneelen et al. ${ }^{17}$ with slight modifications. For analyzing the urinary 2-naphthol, we used the method developed by Kim et al. ${ }^{18}$. In a dark room, $1 \mathrm{ml}$ of the urine samples was buffered with 100 $\mu \mathrm{l}$ of $0.2 \mathrm{M}$ sodium acetate buffer $(\mathrm{pH} 5.0)$ and hydrolyzed enzymatically with $10 \mu \mathrm{l}$ of $\beta$-glucuronidase with sulfatase activity (Sigma G-0876, St. Louis, Mo., USA) for $16 \mathrm{~h}$ at $37^{\circ} \mathrm{C}$ in a shaking water bath. After hydrolysis, $1.5 \mathrm{ml}$ of acetonitrile was added, and the samples were centrifuged at 10,000 g for $10 \mathrm{~min}$. 1-OHP (361518, Sigma-Aldrich) and 2-naphthol (N-1250, Sigma-Aldrich) were used as the standard reagents.

A high-performance liquid chromatography (HPLC) system consisting of a pump (Waters 600E, Millipore, Milford, Mass., USA) and a variable fluorescence detector (RF-10AxL, Shimadzu, Kyoto, Japan) was used. A 150 mm-long reverse phase column (TSK gel ODS-80, Tosoh, Tokyo, Japan) was used for 1-OHP analysis, and a $250 \mathrm{~mm}$-long reverse phase column (J'sphere ODS-H80, YMC, Wilmington, N.C., USA) was used for 2-naphthol analysis. The mobile phase was $60 \%$ acetonitrile for $1-\mathrm{OHP}$ and $38 \%$ acetonitrile for 2-naphthol. The flow rate was 1 $\mathrm{ml} / \mathrm{min}$. The excitation/emission wavelengths used in the detection of 1-OHP and 2-naphthol were 242/288 $\mathrm{nm}$ and 227/355 nm, respectively. The detection limits, which were determined as three times the standard deviation of a blank or unspiked urine sample divided by the slope, 
were $0.13 \mathrm{ng} / \mathrm{ml}$ for 2-naphthol and $0.20 \mathrm{ng} / \mathrm{ml}$ for 1-OHP. The measured values of 1-OHP and 2-naphthol were corrected with the creatinine concentration for the urinary output. The creatinine concentration was measured using Jaffe's reaction.

\section{Statistical analysis}

All the data were computerized. For statistical analysis, SPSS 18.0 for Windows was used. All the measured data were reflected in the geometric mean and the geometric standard deviation. As to the smoking-rate comparison between production jobs and clerical work, the Chi-square test was used for the difference in the 1-OHP and 2-naphthol levels, while the Mann-Whitney $\mathrm{U}$ test was used to compare production jobs and clerical work and the smoking vs. non-smoking groups. The Wilcoxon signed rank test was used to analyze the change in 1-OHP between before and after work. Also, Spearman's coefficient was used to analyze the correlation of 1-OHP and 2-naphthol in relation to the diet and smoking. In addition, by using multiple regression analysis, the concentrations of 1-OHP and 2-naphthol by the job type and smoking were observed.

\section{Results}

\section{General characteristics}

The age and sex distributions of the study subjects by clerical and production workers are shown in Table 1.

\section{The concentrations of 1-OHP and 2-naphthol by jobs and smoking}

The geometric mean (geometric standard deviation) of the concentration of 1-OHP in pro- duction workers was $0.12(3.54) \mu$ mole/mole·Cr., which was significantly higher than that for clerical workers (0.06 (2.60) $\mu$ mole/mole.Cr.; $\mathrm{p}<0.01)$, and the concentration of 2-naphthol in production workers was 2.82 (6.64) $\mu$ mole/ mole.Cr., which was significantly higher than that for clerical workers (1.94 (6.19) $\mu$ mole/ mole.Cr.; $\mathrm{p}<0.05)$.

The corresponding value for the concentration of 1-OHP in smokers was 0.12 (3.50) $\mu$ mole/mole.Cr., which was higher than that for non-smokers (0.08 (3.29) $\mu$ mole /mole.Cr.; p < $0.01)$. The corresponding value for the concentration of 2-naphthol in smokers was 4.27 (6.26) $\mu$ mole/mole·Cr., which was higher than that for clerical workers (1.61 (5.76) $\mu$ mole/mole.Cr.; $\mathrm{p}<$ $0.05)$. The corresponding value for the concentration of 1-OHP in smoking production workers was 0.14 (3.53) $\mu$ mole/mole·Cr., which was higher than that for smoking clerical workers (0.08 (2.61) $\mu$ mole/mole.Cr.). The corresponding value for the concentration of 1-OHP in non-smoking production workers was 0.10 (3.50) $\mu$ mole/mole.Cr., which was higher than that for non-smoking clerical workers (0.05 (2.55) $\mu$ mole/mole.Cr.; $\mathrm{p}<0.01)$. The concentration of 1-OHP in production workers (both smoking and non-smoking) was significantly higher than in clerical workers $(\mathrm{p}<0.05)$. The corresponding value for the concentration of 2-naphthol in smoking production workers was 4.22 (6.80) $\mu$ mole/mole.Cr., which was higher than that for smoking clerical workers (4.24 (4.47) $\mu$ mole/ mole.Cr.). The corresponding value for the concentration of 2-naphthol in non-smoking production workers was $1.73(5.76) \mu$ mole/mole.Cr., which was higher than that for non-smoking clerical workers (1.18 (6.38) $\mu$ mole/mole.Cr.; $\mathrm{p}<$ $0.01)$. But, there were no differences in the concentration of 2-naphthol between smokers and non-smokers in both production and clerical workers (Table 2).

Table 1. The distribution of the subjects by the gender, age group, and type of job.

\begin{tabular}{|c|c|c|c|c|c|c|c|c|c|c|}
\hline \multirow{3}{*}{$\begin{array}{c}\text { Age } \\
\text { (years) }\end{array}$} & \multicolumn{4}{|c|}{ Male } & \multirow{2}{*}{\multicolumn{2}{|c|}{$\frac{\text { Female }}{\text { Clerical workers }}$}} & \multicolumn{4}{|c|}{ Total } \\
\hline & \multicolumn{2}{|c|}{ Clerical workers } & \multicolumn{2}{|c|}{ Production workers } & & & \multicolumn{2}{|c|}{ Clerical workers } & \multicolumn{2}{|c|}{ Production workers } \\
\hline & No & $\%$ & No & $\%$ & No & $\%$ & No & $\%$ & No & $\%$ \\
\hline$<30$ & 3 & 5.0 & 6 & 2.4 & 8 & 66.7 & 11 & 15.3 & 6 & 2.4 \\
\hline $30-39$ & 20 & 33.3 & 85 & 33.5 & 4 & 33.3 & 24 & 33.3 & 85 & 33.5 \\
\hline $40-49$ & 29 & 48.3 & 141 & 55.5 & 0 & 0.0 & 29 & 40.3 & 141 & 55.5 \\
\hline$\geq 50$ & 8 & 13.3 & 22 & 8.7 & 0 & 0.0 & 8 & 11.1 & 22 & 8.7 \\
\hline Total & 60 & 100.0 & 254 & 100.0 & 12 & 100.0 & 72 & 100.0 & 254 & 100.0 \\
\hline
\end{tabular}


Table 2. The concentration of urinary 1-hydroxypyrene (1-OHP) and 2-naphthol by type of job and smoking.

\begin{tabular}{|c|c|c|c|c|}
\hline Smoking (No of cases) & Job ( $\mathrm{N}^{\circ}$ of cases $)$ & Variables & 1-OHP $\left(\mu \mathrm{g} / \mathrm{m}^{3}\right)$ & 2-naphthol $\left(\mu \mathrm{g} / \mathrm{m}^{3}\right)$ \\
\hline \multirow{12}{*}{$\begin{array}{l}\text { Smokers } \\
(167)\end{array}$} & \multirow{6}{*}{$\begin{array}{l}\text { Production workers } \\
\qquad(139)\end{array}$} & AM (ASD) & $0.25(0.38)$ & $9.31(9.85)$ \\
\hline & & GM (GSD) & $0.14(3.53)^{* \dagger}$ & $4.22(6.80)^{\ddagger}$ \\
\hline & & Median & 0.18 & 7.19 \\
\hline & & Minimum & 0.00 & 0.02 \\
\hline & & Maximum & 3.94 & 84.25 \\
\hline & & $95^{\text {th }}$ percentile & 0.60 & 22.72 \\
\hline & \multirow{6}{*}{$\begin{array}{c}\text { Clerical workers } \\
\text { (28) }\end{array}$} & AM (ASD) & $0.13(0.13)$ & $6.79(4.54)$ \\
\hline & & GM (GSD) & $0.08(2.61)^{\dagger}$ & $4.24(4.47)^{\ddagger}$ \\
\hline & & Median & 0.08 & 6.52 \\
\hline & & Minimum & 0.01 & 0.02 \\
\hline & & Maximum & 0.53 & 20.06 \\
\hline & & $95^{\text {th }}$ percentile & 0.48 & 17.69 \\
\hline \multirow{12}{*}{$\begin{array}{c}\text { Non-smokers } \\
(159)\end{array}$} & \multirow{6}{*}{$\begin{array}{c}\text { Production workers } \\
\text { (115) }\end{array}$} & $\mathrm{AM}(\mathrm{ASD})$ & $0.21(0.33)$ & $4.39(6.44)$ \\
\hline & & GM (GSD) & $0.10(3.50)^{*}$ & $1.73(5.76)$ \\
\hline & & Median & 0.11 & 2.34 \\
\hline & & Minimum & 0.00 & 0.02 \\
\hline & & Maximum & 1.92 & 45.94 \\
\hline & & $95^{\text {th }}$ percentile & 0.81 & 15.08 \\
\hline & \multirow{6}{*}{$\begin{array}{c}\text { Clerical workers } \\
\text { (44) }\end{array}$} & $\mathrm{AM}(\mathrm{ASD})$ & $0.08(0.07)$ & $3.35(3.92)$ \\
\hline & & GM (GSD) & $0.05(2.55)$ & $1.18(6.38)$ \\
\hline & & Median & 0.06 & 1.61 \\
\hline & & Minimum & 0.00 & 0.02 \\
\hline & & Maximum & 0.34 & 11.90 \\
\hline & & $95^{\text {th }}$ percentile & 0.26 & 11.70 \\
\hline
\end{tabular}

" $\mathrm{p}<0.01$ for the comparison with the clerical workers group by Mann-Whitney $\mathrm{U}$ test. ${ }^{\dagger} \mathrm{p}<0.05$ for the comparison with the corresponding non-smokers group by Mann-Whitney $\mathrm{U}$ test. ${ }^{\ddagger} \mathrm{p}<0.01$ for the comparison with the corresponding non-smokers group by Mann-Whitney U test. AM : arithmetic mean, ASD : arithmetic standard deviation. GM : geometric mean, GSD : geometric standard deviation.

\section{The changes in the concentration of 1-OHP between before and after working}

We measured the changes in the concentration of 1-OHP between before and after working in 19 cases of the tar production process, 16 cases of the carbon-black production process, and 3 cases of task management (the section concerning the storage of oil) - a total of 38 cases.

The geometric mean (geometric standard deviation) of the concentration of 1-OHP significantly increased from 0.36 (2.81) $\mu$ mole/ mole $\cdot$ Cr. before working to $0.82(2.32) \mu$ mole/ mole.Cr. after working $(\mathrm{p}<0.01)$. The corresponding value for the concentration of 1-OHP in smokers significantly increased from 0.49 (2.66) $\mu \mathrm{mole} / \mathrm{mole} \cdot \mathrm{Cr}$. before working to 0.85
(2.12) $\mu$ mole/mole $\cdot$ Cr. after working $(\mathrm{p}<0.01)$. The corresponding value for the concentration in non-smokers significantly increased from 0.29 (2.83) $\mu \mathrm{mole} / \mathrm{mole} \cdot \mathrm{Cr}$. before working to 0.80 (2.48) $\mu$ mole/mole $\cdot \mathrm{Cr}$. after working $(\mathrm{p}<0.01$; see Figure 2).

\section{The relationship between 1-OHP and the concentration of PAHs}

Urinary 1-OHP concentration increased as $\log (\mathrm{PAHs})$ increased $\left(\mathrm{r}_{\mathrm{s}}=0.675, \mathrm{p}<0.01\right)$. By multiple regression using smoking amount, $1-\mathrm{OHP}=1.121(95 \%$ CI: $0.496-1.745) \times \log$ $(\mathrm{PAHs})\left(\mathrm{R}^{2}=0.448, \mathrm{n}=25\right)$ was derived. Through this equation, we assumed the equation of $\log$ $(\mathrm{PAHs})=0.892 \times 1-\mathrm{OHP}($ see Figure 3$)$. 


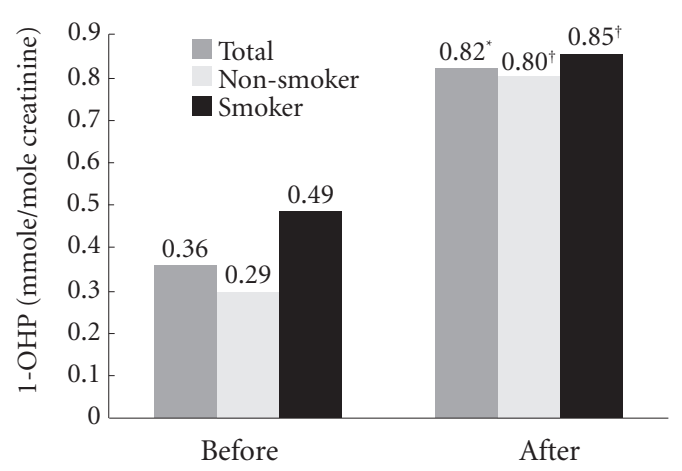

Figure 2. The geometric means of urinary 1-hydroxypyrene (1-OHP) concentration before and after working.

$\mathrm{p}<0.01,{ }^{\dagger} \mathrm{p}<0.05$ by Wilcoxon signed rank test.

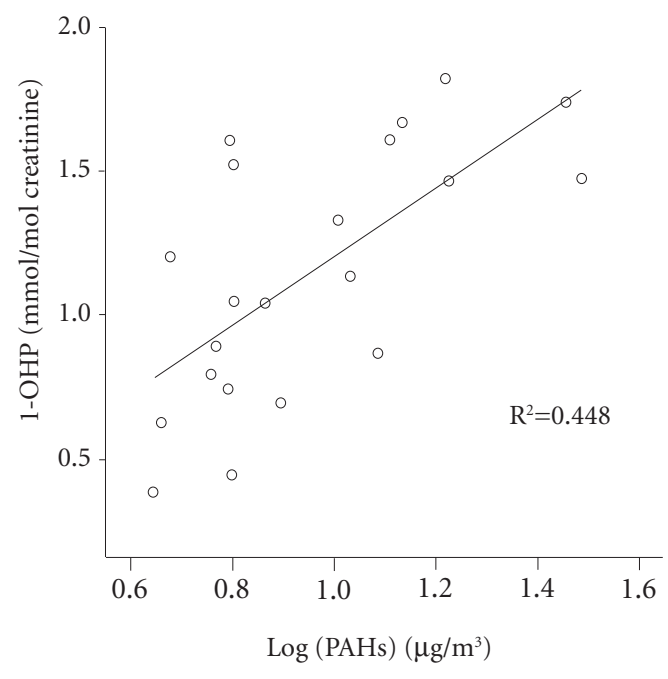

Figure 3. Relationship between urinary 1-hydroxypyrene (1-OHP) concentration and log (PAHs).

\section{The relationship between 1-OHP, 2-naphthol, diet, and smoking}

There was no correlation between 1-OHP, 2-naphthol, and the diet. But the concentration of 1-OHP decreased with the elapsed time after the discontinuation of a task $(\mathrm{p}<0.05)$.
The concentration of 2-naphthol increased with the amount of smoking and decreased with the elapsed time after the cessation of the last smoke $(\mathrm{p}<0.05$, Table 3$)$. In the multiple regression analysis, 1-OHP increased in smokers $(\beta=0.15$, $\mathrm{p}<0.05)$ and production workers $(\beta=0.26$, $\mathrm{p} 0.01)$. Further, 2-naphthol increased in smokers $(\beta=0.43, \mathrm{p}<0.01)$.

\section{Discussion}

As to our results, both occupational and non-occupational exposure to PAHs can exist in this study workplace when existing results ${ }^{18-21}$ are considered whereby 1-OHP is a better indicator than 2-naphthol concerning occupational exposure to PAHs. On the other hand, 2-naphthol is a more sensitive indicator than 1-OHP regarding non-occupational exposure to PAHs. In addition, in multiple regression analysis, 1-OHP is significantly correlated with the type of job and smoking, while 2-naphthol is significantly correlated with only smoking. In this study, the geometric mean (standard deviation) of the overall concentration of 1-OHP and 2-naphthol was respectively 0.10 (3.43) $\mu \mathrm{mole} / \mathrm{mole} \cdot \mathrm{Cr}$. and 2.60 (6.56) $\mu$ mole/mole.Cr. Compared with the study of Kim et al..$^{19}$, the value for 1-OHP was lower than the value of $0.33 \mu$ mole/mole.Cr. for shipyard workers, but that for 2-naphthol was higher than the value of $2.41 \mu \mathrm{mole} / \mathrm{mole} \cdot \mathrm{Cr}$ for shipyard workers. Our results for 1-OHP and 2-naphthol were respectively lower than those of $6.15 \mu$ mole/ mole.Cr. and $6.01 \mu \mathrm{mole} / \mathrm{mole} \cdot \mathrm{Cr}$. for coke work$\mathrm{ers}^{22}$, but higher than the values of $0.04 \mu$ mole/ mole.Cr. and $2.22 \mu$ mole/mole.Cr. for university students ${ }^{20}$. A recent result of 1-OHP for coal tar-handling workers in Korea was $8.89 \sim 19.02$ $\mu$ mole/mole $\cdot \mathrm{Cr}^{23}$. In the study of Ovrebo et al..$^{24}$, the concentration of 1-OHP among residents adjacent to a coke factory area, other manufacturing areas, and non-manufacturing was on average $2.45 \sim 13.48 \mu \mathrm{mole} / \mathrm{mole} \cdot \mathrm{Cr}$., $0.41 \sim 1.54$ $\mu \mathrm{mole} / \mathrm{mole} \cdot \mathrm{Cr}$., and $0.14 \sim 0.20 \mu \mathrm{mole} / \mathrm{mole} \cdot \mathrm{Cr}$., respectively.

The following conclusions of our study can be proposed from the results of various studies in domestic and foreign contexts.

First, the higher concentration of 1-OHP than in university students suggests some occupational exposure in our study factory. However, in spite of emissions of large amounts of PAHs in our study factory, the lower concentration of 1-OHP compared to the case of a factory han- 
Table 3. Spearman's correlation coefficients $\left(r_{s}\right)$ between variables and urinary 1-hydroxypyrene (1-OHP) and 2-naphthol concentration.

\begin{tabular}{|c|c|c|c|c|c|c|}
\hline \multirow[b]{2}{*}{ Variables } & \multicolumn{3}{|c|}{ 1-OHP } & \multicolumn{3}{|c|}{ 2-naphthol } \\
\hline & Total & Smokers & Non-smokers & Total & Smokers & Non-smokers \\
\hline Amount of roasted meat eaten at one time & -0.058 & -0.081 & -0.030 & -0.004 & -0.024 & 0.022 \\
\hline Weekly frequently eating roasted meat & 0.078 & 0.088 & 0.056 & 0.055 & 0.084 & 0.021 \\
\hline $\begin{array}{l}\text { Time after last ingestion of roasted meat } \\
\text { (day) }\end{array}$ & -0.022 & 0.013 & -0.042 & -0.030 & -0.025 & -0.001 \\
\hline Last amount of roasted meat eaten & -0.011 & -0.001 & -0.030 & 0.026 & 0.039 & -0.006 \\
\hline Time lag after stop of the work ${ }^{*}$ & $-0.238^{\dagger}$ & $-0.262^{\dagger}$ & $-0.231^{\ddagger}$ & -0.042 & -0.070 & $-0.208^{\ddagger}$ \\
\hline Duration of smoking (years) & - & -0.024 & - & - & -0.043 & - \\
\hline Amount of daily smoking (cigarettes) & - & 0.046 & - & - & $0.172^{\ddagger}$ & - \\
\hline $\begin{array}{l}\text { Amount of smoking on day before } \\
\text { sampling day (cigarettes) }\end{array}$ & - & 0.072 & - & - & $0.230^{\dagger}$ & - \\
\hline $\begin{array}{l}\text { Amount of smoking on sampling day } \\
\text { (cigarettes) }\end{array}$ & - & 0.129 & - & - & $0.161^{\ddagger}$ & - \\
\hline Time lag after last smoking (minutes) & - & -0.025 & - & - & $-0.192^{\ddagger}$ & - \\
\hline
\end{tabular}

${ }^{*}$ excluded 72 cases of clerical workers. ${ }^{\dagger} \mathrm{p}<0.01 .{ }^{\ddagger} \mathrm{p}<0.05$

dling coke or coal tar means that mechanisms that minimize the exposure including the sealing of the process, sanitation, etc., are in effect. And this means that the occupational exposure is less than in other workplaces.

Second, the facts that the concentration of 1-OHP in this study is lower than for shipyard workers but that of 2-naphthol is higher than for shipyard workers suggest that the exposure sources of PAHs are closely related to lifestyle aspects such as smoking rather than occupational exposure in this study.

In this study, both 1-OHP and 2-naphthol were not related to dietary behaviors. In the study of Kim et al. ${ }^{19}$, the concentration of 1-OHP was related to some dietary behaviors, but in the study of Kang et al. ${ }^{15}$, a significant relationship was not observed. Because it is difficult to measure the exact dietary exposure through a questionnaire survey by categorizing and quantifying the ingestion amount, it is very difficult to discriminate whether the results are due to the measurement of the exposure amount in a wrong way or whether the dietary behaviors in Korea are especially less influenced by PAH exposure. In addition, there is the possibility of being unable to accurately measure the correlation with the diet because the character of data under an ordinal scale cannot conform to equal intervals ${ }^{15}$.

In the case of the smoking habit, in this study, there was no correlation with the concentration of 1-OHP but there was a correlation with the concentration of 2-naphthol. Particularly, the high correlation with the amount smoked on the preceding day of the study is presumed to reflect a characteristic of drug dynamics whereby the excretion volume of PAHs peaks after about 2448 hours following inhalation in the case when PAHs are inhaled through respiratory routes ${ }^{16}$.

In this study, the concentration of 1-OHP in smokers was higher than that of non-smokers. This phenomenon is explained through a toxicological mechanism ${ }^{25}$ whereby the absorption and re-absorption of PAHs increase and/or the process of pyrene metabolism changes through the suppression of the action of cilia in the upper respiratory tract by smoking. Because pyrene is excreted mostly through the urine in the form of 1-hydroxypyrene glucuronide (1-OHPG) or 1hydroxypyrene (1-OHP), the amount of PAHs absorbed is measured through these excretions $s^{16,26-28}$. $1-\mathrm{OHP}^{29,30}$ is known as a sensitive biological exposure indicator that reflects the amount of PAHs absorbed in the human body since it has been introduced as a metabolic product of a pyrene by Jongeneelen et al. ${ }^{17}$. Therefore, urinary 1-OHP as a PAHs metabolite was a strong predictor of cigarette smoking ${ }^{31}$. However, because pyrene can be absorbed through either the respiratory or the gastrointestinal route, it cannot accurately reflect the degree of exposure to PAHs according to the exposed route. However, because naphthalene is mostly absorbed through the respiratory route, and when smoking, one cigarettes contains 2 4 ug of naphthalene, which is equivalent to 100 times of pyren $(0.043 \mathrm{ug})^{32}$, 2-naphthol in urine 
as a metabolite of naphthalene has been developed and widely used ${ }^{18,33}$.

The overall exposure level, as confirmed through this study, was thought not to be higher than in similar workplaces. The great significance of this study conducted for the diagnosis of workplaces was to identify the level of occupational exposure and confirm the presence of non-occupational exposure through smoking besides occupational exposure.

In conclusion, workers in this study workplace were exposed to PAHs through both occupational exposure and lifestyle behaviors such as smoking. Because PAHs are known as hazardous chemicals that induce various health problems including cancer, it may be very important to reduce the exposure to PAHs in this workplace in the future.

For the prevention of occupational exposure, unnecessary leaks are avoided through thorough process management in advance; by the adoption of personal protective measures, exposure to PAHs can be minimized. Furthermore, for preventing exposure through smoking, all workers must cease to smoke, and all areas in the workplace must be smoke-free. Definitely, a periodic survey regarding the workplace environment and metabolites of hazardous materials should be applied for the workplace and for high-risk workers.

\section{Collaborations}

K Lee and HS Lim contributed to designing the study protocol, collection and assembly of data, methodological and statistical analysis and interpretation of the data, drafting of the article, administrative and technical support; H Kim contributed analysis of urine metabolites; All author contributed to manuscript writing and approved the final version of the manuscript. 


\section{References}

1. Stellman SD, Guidotti TL. Polycyclic aromatic hydrocarbons and petroleum industry. In: Rom WN, editor. Environmental and occupational medicine. Philadelphia: Lippincott Williams \& Wilkins; 2007. p. 12401250 .

2. Boffetta P, Jourenkova N, Custavsson P. Cancer risk from occupational and environmental exposure to polycyclic aromatic hydrocarbons. Cancer Causes Control 1997; 8(3):444-472.

3. IARC. Monographs, Some non-heterocyclic polycyclic aromatic hydrocarbons and some related exposures, Volume 92. Lyon: IARC; 2005.

4. IARC. Monographs on the evaluation of the carcinogenic risk to humans. Polynuclear Aromatic Compounds, Part 1: Chemical, Environmental and Experimental Data, Volume 32. Lyon: IARC; 1983.

5. IARC. Monographs on the evaluation of the carcinogenic risk to humans. Polynuclear Aromatic Compounds, Part 2: Carbon Blacks, Mineral Oils (Lubricant Base Oils and Derived Products) and Some Nitroarenes, Volume 33. Lyon: IARC; 1984.

6. IARC. Monographs on the evaluation of the carcinogenic risk of chemicals to humans. Polynuclear Aromatic Compounds, Part 3: Industrial exposures in aluminum production, coal gasification, coke production and iron and steel founding, Volume 33. Lyon: IARC; 1984.

7. IARC. Monographs on the evaluation of the carcinogenic risk to humans, Polynuclear Aromatic Compounds, Part 4: Bitumens, Coal-Tars and Derived Products, Shale-Oils and Soots, Volume 35. Lyon: IARC; 1985.

8. IARC. Overall Evaluations of Carcinogenicity, An Updating of IARC Monographs Volumes 1 to 42, Supplement No. 7. Lyon: IARC; 2005.

9. Harvath PV. Quantitative analysis of multiple PAH's in the coal conversion atmosphere. Am Ind Hyg Assoc J 1983; 44(10):739-745.

10. ACGIH. Documentation of the threshold limit values and biological exposure indices. Cincinnati: ACGIH; 2005.

11. ATSDR. Toxicological profile for wood creosote, coal tar creosote, coal tar, coal tar pitch, and coal tar pitch volatiles. update. Atlanta: Agency for Toxic Substances and Disease Registry; 2002.

12. Lim HS, Lee K. A case of lung cancer occurred to worker handled coal tar. Dongguk J Med 2004; 11:81-88 (in Korean).

13. Kang SK, Ahn YS, Chung HK. Occupational cancer in Korea in the 1990s. Kor J Occup Environ Med 2001; 13(4):351-359 (in Korean).

14. Waldman JM, Lioy PJ, Greenberg A, Butler JP. Analysis of human exposure to benzo(a)pyrene via inhalation and food ingestion in the Total Human Environmental Exposure Study (THEES). J Expo Anal Environ Epidemiol 1991; 1(2):193-225.

15. Kang JW, Cho SH, Kim H, Lee CH. Urinary 1-hydroxypyrene and 2-naphthol as a biological exposure markers of total suspended particulate in the general population. Korean J Prev Med 2000; 33(3):306-312 (in Korean).

16. National Institute of Occupational Safety and Health. Polynuclear aromatic hydrocarbons by GC: method 5515. NIOSH manual of analytical methods. $4^{\text {th }}$ edition. Cincinnati (USA): NIOSH; 1994.
17. Jongeneelen FJ, Anzion RB, Henderson PT. Determination of hydroxylated metabolites of polycyclic aromatic hydrocarbons in urine. J Chromatogr 1987; 413:227232.

18. Kim H, Kim YD, Lee H, Kawamoto T, Yang M, Katoh T. Assay of 2-naphthol in human urine by high-performance liquid chromatography. J Chromatogr B Biomed Sci Appl 1999; 734(2):211-217.

19. Kim H, Lim HS, Kang JW, Lee HI, Kim YD, Nan HM Lee $\mathrm{CH}$. Effects of occupation, life style and genetic polymorphism of CYP1A1, GSTM1, and GSTT1 on urinary 1-hydroxypyrene and 2-naphthol concentration. Korean J Occup Environ Med 1999; 11:546-556 (in Korean).

20. Kim H, Cho SH, Kang JW, Kim YD, Nan HM, Lee CH, Lee $\mathrm{H}$, Kawamoto T. Urinary 1-hydroxypyrene and 2-naphthol concentration in male Koreans. Int Arch Occup Environ Health 2001; 74(1):59-62.

21. Nan HM, Kim H, Lim HS, Choi JK, Kawamoto T, Kang JW, Lee CH, Kim YD, Kwon EH. Effects of occupation, lifestyle and genetic polymorphisms of CYP1A1, CYP2E1, GSTM1 and GSTT1 on urinary 1-hydroxypyrene and 2-naphthol concentration. Carcinogenesis 2001; 22(5):787-793.

22. Yang M, Koga M, Katoh T, Kawamoto T. A study for the proper application of urinary naphthols, new biomarkers for airborne polycyclic aromatic hydrocarbons. Arch Environ Contam Toxicol 1999; 36(1):99-108.

23. Kim EA, LeeJT, Kwon EH, Lee JS, Lee YH, Kwag HS Choi SB, Lee IJ, Shin JH, Shim KJ, Urm SH, Kim SJ, Shon HS, Chun JH. Monitoring of polycyclic aromatic hydrocarbons and the metabolites in workers using coal tar paints. Korean J Occup Environ Med 2005; 17(3):161-172 (in Korean)

24. Ovrebo S, Fieldstad PE, Grzybowska E, Kure EH, Chorazy M, Haugen A. Biological monitoring of polycyclic aromatic hydrocarbon exposure in a highly polluted area of Poland. Environ Health Perspect 1995; 103(9):838-843

25. Jongeneelen FJ, van Leeuwen FE, Oosterink S, Anzion RB, van der Loop F, Bos RP, van Veen HG. Ambient and biological monitoring of cokeoven workers: determinants of the internal dose of polycyclic aromatic hydrocarbons. Br J Ind Med 1990; 47(7):454-461.

26. Buchet JP, Gennart JP, Mercado-Calderon F, Delavignette JP, Cupers L, Lauwreys R. Evaluation of exposure to polycyclic aromatic hydrocarbons in a coke production and a graphite electrode manufacturing plant: assessment of urinary excretion of 1-hydroxypyrene as a biological indicator of exposure. Br J Ind Med 1992; 49(11):761-768

27. Singh R, Tucek M, Maxa K, Tenglerova J, Weyand EH. A rapid and simple method for the analysis of 1-hydroxypyrene glucuronide: a potential biomarker for polycyclic aromatic hydrocarbon exposure. Carcinogenesis 1995; 16(12):2909-2915.

28. Strickland P, Kang D. Urinary 1-hydroxypyrene and other PAH metabolites as biomarkers of exposure to environmental $\mathrm{PAH}$ in air particulate matter. Toxicol Lett 1999; 108(2-3):191-199. 
29. Jongeneelen FJ. Benchmark guideline for urinary 1-hydroxypyrene as biomarker of occupational exposure to polycyclic aromatic hydrocarbons. Ann Occup Hyg 2001; 45(1):3-13.

30. Hansen AM, Poulsen OM, Christensen JM, Hansen SH. Determination of $\alpha$-naphthol in human urine by high performance liquid chromatography. J Liq Chromatogr 1992; 15(3):479-499.

31. Lee KH, Byeon SH. The biological monitoring of urinary 1-hydroxypyrene by PAH exposure among smokers. Int J Environ Res 2010; 4(3):439-442

32. Grimmer G, Naujack KW, Dettbarn G. Gaschromatographic determination of polycyclic aromatic hydrocarbons, aza-arenes, aromatic amines in the particle and vapor phase of mainstream and sidestream smoke of cigarettes. Toxicol Lett 1987; 35(1):117-124.

33. Tingle MD, Pirmohamed M, Templeton E, Wilson AS, Madden S, Kitteringham NR, Park BK. An investigation of the formation of cytotoxic, genotoxic, protein-reactive and stable metabolites from naphthalene by human liver microsomes. Biochem Pharmacol 1993 46(9):1529-1538.

Artigo apresentado em 10/10/2013

Aprovado em 15/05/2014

Versão final apresentada em 18/05/2014 